\title{
Memórias da escola e escolarização
}

FISCHER, Beatriz Terezinha Daudt (Org.). Tempos de escola-Memórias. São Leopoldo: Oikos; Brasília: Líber Livro, 20 12. (v. I, II e III)

Francisco das Chagas Silva Souza Instituto Federal do Rio Grande do Norte

As lembranças da escolarização é o tema tratado pela trilogia organizada por Beatriz Terezinha Daudt Fischer intitulada Tempos de escola Memórias, publicada pelas editoras Oikos e Liber Livros, com prefácio de Maria Stephanou. A organizadora das obras é professora titular da Universidade do Vale do Rio dos Sinos - Rio Grande do Sull e tem larga produção acadêmica no campo da História da Educação, com ênfase em histórias de vida, memórias, trajetórias docentes e discentes, história de instituições escolares.

Desde 2011 , quando publicou os dois primeiros volumes de Tempos da escola, Fischer tem investido na grata, mas não fácil, tarefa de reunir relatos autobiográficos de alguns dos renomados pesquisadores brasileiros da atualidade no campo da Educação. Ao todo, os três livros contam com 41 textos nos quais os autores convidados pela organizadora das obras narram algumas experiências vividas na formação escolar.

A disposição de Fischer em organizar a referida trilogia insere-se no contexto da expansão das pesquisas com o uso das narrativas autobiográficas, cujas origens se encontram na "emergência" da História Oral no Brasil, na década de 1970. Assim, longe da rigidez do método científico, consolidado no século XIX, a memória passa a ser percebida pelos historiadores como capaz de revelar um passado negligenciado pela história oficial. Altera-se, assim, a compreensão do que seja uma fonte histórica.

Não obstante as críticas que a chamada abordagem biográfica recebeu (e ainda recebe), nas últimas décadas, ela adquiriu espaços em eventos científicos, o que permitiu a criação de associações por meio das redes nacionais e regionais de pesquisa. Exemplo disso é a Associação Internacional das Histórias de Vida em Formação (ASIHVIF), criada em fins da década de 1980, na França, no contexto do movimento conhecido como "histórias de vida em formação", e, no Brasil, a Associação Norte e Nordeste das Histórias de Vida 
em Formação (ANNIHVIF), em 2007. Também, no nosso país, é importante destacar a realização do Congresso Internacional sobre Pesquisa (Auto)Biográfica que, em 2014, teve sua sexta edição, e a fundação da Associação Brasileira de Pesquisa (Auto)Biográfica (BIOGRAPH), em 2008.

Fora desse contexto acadêmico favorável, as obras organizadas por Fischer talvez nem chegassem a existir, ou, caso fossem publicadas, certamente teriam pouca receptividade, pois a academia estava mais voltada para temas em que a memória pessoal não era valorizada enquanto documento.

Imbuída de novas ideias, Fischer introduz as obras que compõem a trilogia com uma belíssima metáfora. Para ela, da mesma forma que as enguias, quando capturadas, sobrevivem por algum tempo devido a uma reserva de água que guardam em suas brânquias, somos também capazes de resistir porque armazenamos lembranças.

Por acreditar no potencial da narrativa em dar ânimo à memória, a organizadora convidou alguns dos seus colegas da academia para pensar e escrever sobre seus tempos de escola. Certamente, para muitos destes, o convite thes pareceu um enorme desafio, haja vista que são mais conhecidos pelos seus nomes nas capas dos livros, pelas autorias de artigos em periódicos e pelas presenças em eventos científicos, que pela sua "vida real", os bastidores de suas formações pessoal e acadêmica. Desse modo, a escrita que iriam produzir exigiria introspecção, disciplina, escolhas, exames de consciência, isto porque a expressão da memória, a partir de narrativas, orais ou escritas, é um processo contínuo de reconstrução, atualização e transformação das experiências relembradas.

Dessa maneira, quando expomos o nosso passado, mesmo uma pequena parte deste, caminhamos em busca de nós mesmos, de nossas origens, de nossos encontros, desencontros, conquistas e derrotas. Essa escrita de si não é fácil, pois, nela, procuramos compreender o que fomos e o que somos. Significa dizer que narrar o passado é tecer uma identidade, é compor um passado com o qual possamos conviver. Thomson (1997, p. 57) adverte: "Ao narrarmos uma história, identificamos o que pensamos que éramos no passado, quem pensamos ser no presente e o que gostaríamos de ser. [...] podemos dizer que nossa identidade molda nossas reminiscências; quem acreditamos que somos no momento e o que queremos ser afetam o que julgamos ter sido". 
Na composição do nosso passado, nunca o teremos como um tabuleiro de xadrez, com todos os quadrados iguais, mas como uma colcha de retalhos - no dizer de Portelli (1997, p. 16) - em que os pedaços, apesar de diferentes, formam um todo coerente depois de reunidos.

Assim, ao serem despertados (ou desafiados) a escreverem sobre si, os 41 quarentas e um intelectuais de Tempos de escola, decerto viram-se às voltas com perguntas como: "por onde começar?", "como me tornei o(a) professor(a) que sou?", "o que posso ou devo relatar sobre o meu passado escolar?". Ou, mais intimamente, nos recônditos de sua consciência: "como eu me vejo e quero que me vejam?".

Partindo de perguntas como essas, alguns ousaram realizar uma síntese de várias décadas de trajetória escolar; outros preferem destacar um período desse percurso ou um fato que thes foram marcantes. Os textos, todos muito bem escritos, provocam vários sentimentos no leitor. Eles nos fazerem sorrir, chorar, encontrarmo-nos nas experiências descritas no texto. Não são poucas as vezes que nos lembramos de situações semelhantes. Tinha razão Foucalt (1992, p. 145) ao ressaltar que "[...] a carta enviada actua, em virtude do próprio gesto da escrita, sobre aquele que a envia, assim como actua, pela leitura e a releitura, sobre aquele que a recebe".

Na escrita de si, os narradores, consciente ou inconscientemente, revelam-se ao público leitor. Uns demonstram suas veias literárias já no título do texto ou na forma como o escrevem (merece realce a narrativa que Lúcio Kreutz faz a respeito do dia do próprio nascimento); outros, discorrem sobre si, mas não se liberam do rigor que a academia exige em uma produção textual. De uma forma ou de outra, todos mostram a sua "cara" ou a "cara" que desejam para si.

Malgrado hajam distinções, em todas as narrativas, em maior ou menor escala, encontramos elementos de uma época (fatos históricos, mudanças no espaço), aspectos do cotidiano familiar (relações de gênero, orientação e apoio dos pais), da arquitetura da escola, do currículo e da cultura escolares. Situações constrangedoras também estão presentes. Digna de destaque é aquela vivida por Alfredo Veiga-Neto, que, quando criança, foi acusado inocentemente de ter usado cola.

Nessas narrativas, o elemento surpresa está sempre presente. Como não nos espantarmos ao ler uma passagem em que Maria Isabel da Cunha, uma intelectual de ilibado prestígio, diz ter sido uma aluna relapsa? 
Enfim, as obras organizadas por Fischer demonstram a riqueza que as narrativas podem oferecer aos pesquisadores da História da Educação, haja vista que elas não apenas revelam práticas em tempos e espaços distintos Itornando-se recursos para a produção do conhecimento no âmbito do campo educacional), mas também porque nos educa, ensinando-nos a sentir as experiências vividas por outros sujeitos, e, muitas vezes, possibilitando-nos um encontro com o nosso próprio eu.

\title{
Referências
}

FOUCAULT, Michel. A escrita de si. In: O que é um autor? Lisboa: Passagens, 1992.

PORTELLI, Alessandro. Tentando aprender um pouquinho: algumas reflexões sobre a ética na História Oral. Projeto História, São Paulo, v. 15, p. 13-33, abr. 1997.

THOMSON, Alistair. Recompondo a memória: questões sobre a relação entre a história oral e as memórias. Projeto História, São Paulo, v. 15, p. 51-84, abr. 1997.

\author{
Prof. Dr. Francisco das Chagas Silva Souza \\ Instituto Federal do Rio Grande do Norte \\ Professor do Programa de Pós-Graduação em Educação Profissional \\ E-mail | chagas.souza@ifrn.edu.br
}

Recebido 2 ago. 2015 Aprovado 2 set. 2015 